\title{
The Effectiveness of Dictionary Examples in Decoding: The Case of Kuwaiti Learners of English*
}

\author{
Hashan Al-Ajmi, Department of English, Faculty of Arts, \\ Kuwait University, Kuwait (hashan98@yahoo.com)
}

\begin{abstract}
This study tries to shed light on the role of dictionary examples in the comprehension of word meanings. An experimental procedure has been devised whereby two groups of students with English as major subject at Kuwait University were asked to provide the Arabic equivalents for ten English headwords. The first group was given a list of entries for these words copied from the Oxford Advanced Learner's Dictionary (OALD) while the second group had to read the same list but without illustrative examples. Results indicate that the students' decoding performance was negatively affected by the presence of illustrative examples in the dictionary entry.
\end{abstract}

Keywords: ARABIC, BILINGUAL DICTIONARY, COMPREHENSION, EFL DICTIONARY, ILLUSTRATIVE EXAMPLE, MONOLINGUAL DICTIONARY, TRANSLATION

Opsomming: Die doeltreffendheid van woordeboekvoorbeelde by dekodering: Die geval van Koeweiti-aanleerders van Engels. Hierdie studie probeer lig werp op die rol van woordeboekvoorbeelde by die verstaan van woordbetekenisse. 'n Eksperimentele metode is ontwerp waarby twee groepe studente met Engels as hoofvak by die Universiteit van Koeweit gevra is om Arabiese ekwivalente vir tien Engelse trefwoorde te verskaf. Aan die eerste groep is 'n lys inskrywings van hierdie woorde oorgeneem uit die Oxford Advanced Learner's Dictionary (OALD) gegee, terwyl die tweede groep dieselfde lys moes lees, maar sonder verduidelikende voorbeelde. Resultate het aangedui dat die studente se dekoderende prestasie negatief beïnvloed is deur die teenwoordigheid van verduidelikende voorbeelde in die woordeboekinskrywing.

Sleutelwoorde: ARABIES, TWEETALIGE WOORDEBOEK, BEGRIP, EVT-WOORDEBOEK, VERDUIDELIKENDE VOORBEELD, EENTALIGE WOORDEBOEK, VERTALING

\section{Introduction}

Verbal illustrations have always been considered an essential component of dictionary entries and a criterion by which metalexicographers and reviewers evaluate dictionaries. However, as shown in various lexicographic traditions,

* This article is a revised version of a paper 'The Effectiveness of EFL Dictionary Examples in Kuwaiti Learners' Comprehension of Entry Words' presented at the Thirteenth International Symposium on Lexicography, University of Copenhagen, Copenhagen, Denmark, 3-5 May 2007. 
illustrative examples have no clearly defined or agreed-upon functions. In the past, exemplification was utilized in Arabic dictionaries in the form of quotations aimed at proving the existence of rare words in the language. Arab lexicographers took these illustrative examples mainly from the Quran, Hadith and poetry (Al-Kasimi 1977). In the lexicographic heritage of English, Johnson was the first to use examples systematically to illustrate the words defined in the entries. His examples were taken from the writings of great authors like Shakespeare, Milton, Dryden and Addison (Cowie 1990). The appearance of EFL dictionaries such as the Oxford Advanced Learner's Dictionary (OALD) in 1947 has marked a new trend in which dictionary examples were revised and increased to perform an essential function, i.e. to illustrate grammatical patterns and throw light on the meaning of the entry (Hornby 1965). A detailed description classifying the functions of illustrative examples into active and passive functions has been provided by Drysdale (1987: 218): to supplement information in a definition, to show the entry word in context, to distinguish one meaning from another, to illustrate grammatical patterns, to show other typical collocations and to indicate appropriate registers or stylistic levels.

Thanks to the information revolution, the electronic corpus has become the main source of dictionary examples, and one EFL dictionary, the Collins COBUILD English Language Dictionary, relies entirely on a corpus for its examples (cf. Sinclair 1987). Yet some lexicographers still prefer to invent their examples. Cowie (1989: 62) stresses 'the role of the dictionary compiler as the deliberate controller and manipulator of illustrative material' and defends the traditional invented examples because they can be shaped in the learners' interests. He also believes that the extensive use of examples is an alternative (or necessary addition) to clearer labelling as a means of indicating syntactic patterns and advises that examples taken from actually occurring texts should not be accorded a sacred status (Cowie 1989: 45). Also, Minaeva (1992) argues for examples created by lexicographers rather than examples taken out of context from a large corpus while Mitmann (1995) criticizes the corpus examples of COBUILD because of their length and complexity. On the other hand, there are those who regard a corpus as a reliable source of illustrative material. Indeed, all modern EFL dictionaries depend to different degrees on corpus data in every aspect of their text, so the differences now lie in the degree to which corpus material is processed on its way to the examples (Rundell 1998: 334). Criticism is often voiced against invented examples by corpus proponents like Sinclair (1984: 4) who states that 'when examples are concocted by the same lexicographer, they have no value at all. It can be claimed that they illustrate the word in use, but one thing we do know is that usage cannot be thought up - it can only occur'. Atkins (1991) illustrates how concordances of a corpus are useful in constructing fuller entries with a finer breakdown of senses. As to the users, Humblé (1998) argues that advanced users can benefit from authentic corpus examples, while intermediate learners can learn from 'controlled' exam- 
ples, and Potter (1998) indicates that carefully chosen corpus examples are more helpful for users of English learners' dictionaries than invented examples. However, users in different parts of the world still face serious difficulties trying to extract dictionary explanatory and illustrative data in both the decoding and encoding modes. For example, Kharma (1984) observes that most students at Kuwait University use a bilingual dictionary all the time and that these students seem to have difficulty in understanding the definitions used in their English monolingual dictionaries. This observation is shared by El-Badry (1990) in whose study of Arab students' dictionary use the subjects said that they find monolingual dictionaries difficult to use because their definitions are ambiguous and their examples insufficient. In Hong Kong, Chi (1998) also found that most university students own a bilingual English-Chinese dictionary for comprehension, but that very few students own monolingual English learners' dictionaries, a possible indication of their difficulties with them. But bilingual dictionaries may not provide the needed information. In the study by Marello (1987: 236) of Italian students' views of their bilingual dictionaries, results of the questionnaire show that examples are not sufficiently informative.

The availability of examples in the dictionary entry does not mean that users would be able to utilize the information. Only those who know how to read them can achieve that objective (Maingay and Rundell 1987). It is impossible for a dictionary to provide all possible constructions, collocations and contexts of usage of a given word. Another inherent shortcoming of exemplification is outlined by Whitcut (1985: 77): 'Examples can show how a word can be used, but not how it can't.' A detailed account of the problems associated with dictionary examples and definitions is given by Creamer (1987). These problems include: an incomplete definition in the entry combined with a poor example, a lack of sense discrimination in the example, inappropriate placement of the example in the entry, and the absence of examples. He refers to problems with definitions indicating that definitions written too broadly or too narrowly may confuse users.

Entries combining definitions with examples may affect users' response to the data of the entry. In their experiment, Cumming et al. (1994) found that students preferred COBUILD's sentence definitions plus a usage example $(71 \%)$ over the phrasal definitions plus examples $(27 \%)$ in the Longman Dictionary of Contemporary English (LDOCE). And Herbst (1986) found that users had more success in comprehending entries constructed with a controlled vocabulary in comparison to the non-controlled dictionary. But difficulties with monolingual definitions are not restricted to foreign learners of English. McKeown (1991) found that young native speakers do not learn much from the traditional dictionary format and that revised definitions yielded better results.

The issue of illustrative examples in English lexicography is summarized by Jackson (2002: 181): 'Examples are seen as playing a crucial role in EFL dictionaries. A number of questions need to be asked by the critic, relating to: the 
extent of the use of examples, what role they are seen to play in exemplification, where the examples come from (corpus or invented), and how consistently the dictionary's policy on examples is implemented.'

\section{Previous studies on examples}

A few studies dealt with the issue of the presence versus absence of examples in the dictionary entry as well as the issue of whether examples should be invented or derived from a corpus. As for corpus derived examples, Laufer (1992) conducted a test to determine the effectiveness of the two types in the comprehension and use of new vocabulary items. Her results indicated that invented examples were more effective than COBUILD's corpus examples. And in 1993 Laufer performed another experiment to discover the effect of dictionary definitions and examples on the use, comprehension and translation of new L2 words by 43 first-year students at the Hebrew University. Some of the subjects were given definitions, another group were given examples while the third group dealt with combined entries, i.e. both a definition and an example. Results of her study showed that a combined entry yields the best results in comprehension and that a definition alone is better than only an example. Laufer (1993: 139) found that 'the understanding of new words improves more when a definition is added than when an example is added ... in production, unlike in comprehension, an example alone will be just as efficient as a definition alone'.

In another study by Nesi (1996), 40 non-native speakers of English studying in Britain were tested to discover how much help examples can be in the productive use in sentences of 18 unfamiliar words. Two versions were prepared taking entries from LDOCE. In the first version, examples were removed from the first half of the entries and from the second half of the second version. Nesi (1996: 201) found that 'there was ... no statistical evidence that subjects were more productively competent when they were provided with illustrative examples'. A more recent study (Al-Bader 2007) tested Kuwait University students using four EFL dictionaries to verify the effectiveness of definitions only versus definitions plus examples. However, Al-Bader (2007: 101) found that 'results were not enough to decide whether the existence of sentences along with definitions play a substantial role in understanding the meaning of English words, as most of the students have identified the meaning of the words with or without the assistance of illustrative examples'.

It is noticeable that previous studies put more focus on the role of examples in production and less on comprehension. But it is known from several user studies (e.g. Battenburg 1991, Al-Ajmi 1992, etc.) that both types of dictionary are mostly used for decoding rather than encoding linguistic activities (also see Cowie 1999). 


\section{The study}

Given the discrepancy in the results of previous studies, the present investigation aims to test the effectiveness of illustrative examples when using the EFL dictionary to understand unfamiliar words. Hence, the focus will be on reading comprehension since it is the linguistic activity in which learners often refer to their dictionaries. The study tries to find answers to the following research questions:

(1) Is the presence of an example better than its absence in the EFL dictionary when used for comprehension?

(2) Are there any specific patterns followed by students as shown in their translations?

(3) How close are their translations to bilingual dictionary equivalents?

Ten words were selected and pilot-tested to ascertain their difficulty. They are: aftermath, aisle, bona fide, deflect, elide, grandeur, lingua franca, ominous, repulsive, restive. The pilot test has shown that the majority of respondents were in need of consulting their dictionaries for the test items either for total lack of knowledge or uncertainty about their meanings. Items that were to be looked up as a result of uncertainty (i.e. the student wanted to double check) were included in the list as this reflects a real situation of dictionary use. Dictionaries are sometimes consulted even when the meaning of a word can be guessed. Therefore, all the test items are expected to be looked up by the majority in real-life dictionary consultation. A list containing the entries of these words was taken from the OALD and two versions were prepared, one with definitions plus examples (see Appendix I) and the other with definitions only (see Appendix II).

The subjects of this study were 54 juniors at the Department of English, Faculty of Arts, Kuwait University enrolled in translation courses as well as English writing and conversation courses, all of which require extensive use of both bilingual and monolingual English dictionaries. Half of them were asked to translate the headwords after carefully reading the relevant definitions and examples. The other half of the subjects were asked to read the definitions only, then translate the headwords. Translation here is used as a tool for measuring how well the words were understood by this linguistically homogeneous group. It is believed that this method may yield more accurate results than composition of sentences containing the test words. The latter method may lead students to produce sentences that simulate the examples or definitions and do not guarantee that it will be known for certain whether the subjects understood the meanings of the entry words. Moreover, when writing, a student may adopt some strategies that conceal his/her inability to understand word meanings, and examples, according to Nesi (1996: 203), do not prohibit the use of alternative structures. It is not possible in this study which deals with 
one dictionary title to determine whether examples derived from a corpus excel over those invented by lexicographers or vice versa. Also, the study does not concern itself with revealing user preferences with regard to types of examples as in the investigation by Cumming et al. (1994).

Correct and incorrect responses were determined by comparing students' translations with Arabic equivalents in the English-Arabic dictionary Al-Mawrid, the most popular bilingual dictionary in the Arab world. Accordingly, responses were analyzed, then classified into the following:

(1) The translation is correct and identical with Al-Mawrid

(2) The translation is correct and synonymous with Al-Mawrid

(3) No translation has been given

(4) The wrong translation is given

(5) The translation is a derivative, but related to Al-Mawrid

(6) The translation is a derivative, but unrelated to Al-Mawrid

Thereafter comparisons were made between translations given by those who read definitions only and translations by those who used definitions plus examples. Table 1 below shows the classification of the results of the two groups:

Table 1: Categories of student responses

\begin{tabular}{|l|c|c|c|c|}
\hline Category & $\begin{array}{c}\text { Definition } \\
\text { only } \\
(\mathrm{n}=270)\end{array}$ & $\begin{array}{c}\text { Definition } \\
+ \text { Example } \\
(\mathrm{n}=270)\end{array}$ & $\%$ \\
\hline $\begin{array}{l}\text { The translation is correct and } \\
\text { identical with Al-Mawrid }\end{array}$ & 34 & 12.6 & 20 & 7.4 \\
\hline $\begin{array}{l}\text { The translation is correct and } \\
\text { synonymous with Al-Mawrid }\end{array}$ & 23 & 8.5 & 16 & 5.9 \\
\hline No translation has been given & 97 & 35.9 & 123 & 45.6 \\
\hline $\begin{array}{l}\text { The wrong translation is given } \\
\text { The translation is a derivative, but } \\
\text { related to Al-Mawrid }\end{array}$ & 13 & 4.8 & 10 & 3.7 \\
\hline $\begin{array}{l}\text { The translation is a derivative, but } \\
\text { unrelated to Al-Mawrid }\end{array}$ & 35 & 13.0 & 33 & 12.2 \\
\hline
\end{tabular}

The above categories are used as indicators of the students' ability to understand information in the dictionary entry (categories 1,2 and 5) or their inability to do so (categories 3, 4 and 6). 


\section{Results and discussion}

The results show a significant discrepancy between the two sets of wrong translations, i.e. by those using definitions only and those using definitions plus examples. Students translating the headwords with the help of definitions plus examples made more errors than those who relied on definitions only. Out of the 327 instances in categories 3, 4, and 6 that indicate inability to comprehend the entry $155(47.4 \%)$ were associated with the use of definitions only while $172(52.6 \%)$ were recorded for those who used definitions plus examples. There were no statistically significant differences between the two groups with regard to the derivationally inaccurate translations. Therefore, it can be seen that students' ability to comprehend words was less when definitions were combined with examples.

When explaining these results which indicate the ineffectiveness of examples the EFL dictionary itself may have to be addressed. This dictionary type is supposed to depart from the definitional style of native-speaker dictionaries, i.e. by providing simplified definitions that contain high-frequency words or controlled vocabulary. It seems that this objective has been achieved and that most problems still relate to the examples (cf. Creamer 1987). The first function of an example as described by Drysdale (1987), to supplement information in a definition, has not been realized in a way that facilitates users' success in comprehending word meanings. It appears that the policy followed in the construction of definitions in the OALD excels over that adopted in its examples. The language of its definitions might be easier and clearer than the language of the examples which might contain other unfamiliar words, thus leading to confusion and more text to be processed by the definition-plus-example group. This is shown in the large number of student equivalents that translate some words in the examples or definitions instead of the entry words. Perhaps these students thought that the example contains synonyms of the entry word and decided to translate these familiar words in the example. This tendency to focus on easy words in a definition or example has also resulted in translations of words with different parts of speech from the headwords. For example, the headword repulsive was translated by some students with the Arabic noun kurh, a direct equivalent of dislike in the definition, an indicator of the students' habit of not reading the whole text of the entry but stopping at the point where they think the needed information has been found. This occurred despite the presence of examples showing that repulsive is an adjective: a repulsive sight/ smell/person/habit. This pattern may be explained with reference to the vocabulary and structure of definitions as well. Easy words in some definitions belong to a different part of speech as in the entry for the word grandeur. Some students translated the word great in the definition 'the quality of being great' into its corresponding Arabic adjective. It seems that the use of easier English synonyms of the headword would here have yielded better results owing to better understanding of the entry word. Also, it was noticed that students tend 
to concentrate on the first easy word in the definition or example even when there is more than one sense. For example, the term bona fide was given the Arabic translation of 'legal', the third sense in its entry after 'genuine' and 'without deception'.

These results may also be explained by the fact that these learners are accustomed to the use of the bilingual dictionary where quick answers in the form of translation equivalents in the native language can be found. The test items (definitions plus examples) confronted the subjects with longer answers in the foreign language thus leading to more difficulties with the dictionary text.

The results show a low number of correct translations identical to AlMawrid equivalents in the case of definitions only (12\%) against $7.4 \%$ for definitions plus examples. A possible explanation is that a shorter entry, without examples, means less distraction, thus enabling the subjects better to concentrate on the general concept of the word in Arabic. However, these translations were fewer than those that were correct but not listed in Al-Mawrid. The policy followed in this bilingual dictionary of providing a few Arabic synonyms that often do not agree with students' expectations should therefore be revised. The same state of affairs is noticed with translations presented by students, as most of their responses in this category were not related to the dictionary equivalents. This may also be attributed to the diglossic situation of Arabic which results in differences between the lexical repertoire employed in ideal written forms and the mental lexicon shared by Arab students.

\section{Conclusions}

This study has found that the provision of examples along with definitions negatively affects students' ability to understand unfamiliar English words. This finding clearly contradicts the common belief that examples are useful in both comprehension and production. It should, nevertheless, lead dictionary makers to think seriously about solutions to problems of constructing examples and definitions. EFL learners may be in need of easier examples and new ways for the construction of definitions, taking into account the problems faced by these learners when sorting through dictionary information (cf. Al-Ajmi 2002). Corpus data coupled with research-based knowledge of EFL learners' needs can be utilized in compiling more user-friendly dictionaries. A combination of both corpus examples and invented examples seems to be the viable approach that guarantees the provision of natural and usable examples. On the other hand, students need to be taught how to use their EFL dictionaries effectively and made aware of the information systems therein. As for studies on the role of examples in comprehension, researchers may obtain more accurate results if they opt for other research methods such as think-aloud protocols in order to understand what goes on in the users' minds while reading a dictionary entry. 


\section{References}

Al-Ajmi, H. 1992. The Use of Monolingual and Bilingual Arabic-English Dictionaries in Kuwait: An Experimental Investigation into the Dictionaries Used and Reference Skills Deployed by University Students of Arts and Science. Unpublished Ph.D. Thesis. Leeds: University of Leeds.

Al-Ajmi, H. 2002. Which Microstructural Features of Bilingual Dictionaries Affect Users' Look-Up Performance? International Journal of Lexicography 15(2): 119-131.

Al-Bader, Y. 2007. The Provision of Illustrative Examples in English Advanced Learners' Dictionaries. Unpublished M.A. Thesis. Bangor: University of Wales.

Al-Kasimi, A.M. 1977. Linguistics and Bilingual Dictionaries. Leyden: E.J. Brill.

Atkins, B.T. 1991. Corpus Lexicography: The Bilingual Dimension. Zampolli, A. et al. (Eds.). 1991. Computational Lexicology and Lexicography. Vol. I: 43-64. Pisa: Giardini Editori E Stampatori.

Atkins, B.T. and K. Varantola. 1998. Monitoring Dictionary Use. Atkins, B.T. (Ed.). Using Dictionaries. Studies of Dictionary Use by Language Learners and Translators: 83-122. Lexicographica. Series Maior 88. Tübingen: Max Niemeyer.

Battenburg, J. 1991. English Monolingual Learner's Dictionaries: A User-Oriented Study. Lexicographica. Series Maior 39. Tübingen: Max Niemeyer.

Chi, M. 1998. Teaching Dictionary Skills in the Classroom. Fontenelle, T. et al. (Eds.). 1998: 565-577..

Cowie, A.P. 1989. The Language of Examples in English Learners' Dictionaries. James, G. (Ed.). 1989. Lexicographers and their Works: 55-65. Exeter Linguistic Studies 14. Exeter: University of Exeter.

Cowie, A.P. 1990. Language as Words: Lexicography. Collinge, N.E. (Ed.). 1990. An Encyclopedia of Language: 671-700. London/New York: Routledge.

Cowie, A.P. 1999. English Dictionaries for Foreign Learners. A History. Oxford: Clarendon Press.

Cowie, A.P. (Ed.). 1987. The Dictionary and the Language Learner. Papers from the EURALEX Seminar at the University of Leeds, 1-3 April 1985. Lexicographica. Series Maior 17. Tübingen: Max Niemeyer.

Creamer, T. 1987. Beyond the Definition: Some Problems with Examples in Recent Chinese-English and English-Chinese Bilingual Dictionaries. Cowie, A.P. (Ed.). 1987: 238-245.

Crowther, J. (Ed.). 1995. Oxford Advanced Learner's Dictionary of Current English. Fifth Edition. Oxford: Oxford University Press.

Cumming, G. et al. 1994. On-line Lexical Resources for Language Learners: Assessment of Some Approaches to Word Definition. System 22(3): 369-377.

Drysdale, P.D. 1987. The Role of Examples in a Learner's Dictionary. Cowie, A.P. (Ed.). 1987: 213223.

El-Badry, N. 1990. Arabic Lexicography in Northern Africa, with Special Reference to Egypt. Hartmann, R.R.K. (Ed.). 1990. Lexicography in Africa: 36-43. Exeter Linguistic Studies 15. Exeter: University of Exeter Press.

Fontenelle, T. et al. (Eds.). 1998. Actes EURALEX'98 Proceedings. Papers Submitted to the Eighth EURALEX International Congress on Lexicography in Liège, Belgium: 565-577. Liège: English and Dutch Departments, University of Liège.

Hartmann, R.R.K. 1983. The Bilingual Learner's Dictionary and its Uses. Multilingua 2(4): 195-201.

Hartmann, R.R.K. (Ed.). 1984. LEXeter '83 Proceedings. Papers from the International Conference on Lexicography at Exeter, 9-12 September 1983. Lexicographica. Series Maior 1. Tübingen: Max Niemeyer. 
Herbst, T. 1986. Defining with a Controlled Defining Vocabulary in Foreign Learners' Dictionaries. Lexicographica 2: 101-119.

Hornby, A.S. 1965. Some Problems of Lexicography. English Language Teaching 19(3): 104-110.

Humblé, P. 1998. The Use of Authentic, Made-up, and 'Controlled' Examples in Foreign Language Dictionaries. Fontenelle, T. et al. (Eds.). 1998: 593-599.

Humblé, P. 2001. Dictionaries and Language Learners. Frankfurt: Haag und Herchen.

Jackson, H. 2002. Lexicography. An Introduction. London/New York: Routledge.

Kharma, N. 1984. Contextualization and the Bilingual Learner's Dictionary. Hartmann, R.R.K. (Ed.). 1984: 199-206

Laufer, B. 1992. Corpus-based versus Lexicographer Examples in Comprehension and Production of New Words. Tommola, H. et al. (Eds.). 1992: 71-76.

Laufer, B. 1993. The Effect of Dictionary Definitions and Examples on the Use and Comprehension of New L2 Words. Cahiers de lexicologie 63(2): 131-142.

Maingay, S. and M. Rundell. 1987. Anticipating Learners' Errors - Implications for Dictionary Writers. Cowie, A.P. (Ed.). 1987: 128-135.

Marello, C. 1987. Examples in Contemporary Italian Bilingual Dictionaries. Cowie, A.P. (Ed.). 1987: 224-237.

McKeown, M. 1991. Learning Word Meanings from Definitions. Problems and Potential. Schwanenflugel, P. (Ed.). 1991. The Psychology of Word Meanings: 137-156. Hillsdale, NJ: Lawrence Erlbaum.

Minaeva, L. 1992. Dictionary Examples: Friends or Foes? Tommola, H. et al. (Eds.). 1992: 77-80.

Mitmann, B. 1995. Examples in English Monolingual Dictionaries. Unpublished M.A. Thesis. Erlangen-Nürnburg: Friedrich-Alexander University.

Nesi, H. 1996. The Role of Illustrative Examples in Productive Dictionary Use. Dictionaries 17: 198206.

Potter, L. 1998. Setting a Good Example: What Kind of Examples Best Serve the Users of Learners' Dictionaries? Fontenelle, T. et al. (Eds.). 1998: 357-362.

Rundell, M. 1998. Recent Trends in English Pedagogical Lexicography. International Journal of Lexicography 11 (4): 314-342.

Sinclair, J. 1984. Lexicography as an Academic Subject. Hartmann, R.R.K. (Ed.). 1984: 3-12.

Sinclair, J. (Ed.). 1987. Looking Up. An Account of the COBUILD Project in Lexical Computing and the Development of the Collins COBUILD English Language Dictionary. London/Glasgow: Collins.

Tommola, H. et al. (Eds.). 1992. EURALEX '92 Proceedings. Papers Submitted to the 5th EURALEX International Congress on Lexicography in Tampere, Finland, 4-9 August 1992. Studia Translatologica. Serie A(1-2). Tampere: Department of Translation Studies, University of Tampere.

Whitcut, J. 1985. Usage Notes in Dictionaries: The Needs of the Learner and the Native Speaker. Ilson, R. (Ed.). 1985. Dictionaries, Lexicography and Language Learning: 75-80. ELT Documents 120. Oxford: Pergamon Press. 
Appendix I: List of test entries (definition plus example)

1. aftermath $n$ (usu sing) the circumstances that follow and are a consequence of an event, esp of an unpleasant one: the rebuilding which took place in the aftermath of the war.

2. aisle $n$ a passage between rows of seats in a church, theatre, railway carriage, etc or between rows of shelves in a shop: The bride and groom walked slowly down the aisle (ie after their wedding ceremony) $\circ$ An aisle seat (ie one next to the passage in an aircraft etc).

3. bona fide adj [esp attrib], adv genuine(ly); without deception; legal(ly): $a$ bona fide agreement/contract/deal.

4. $\quad$ deflect $v$ change or make sth change direction, esp after hitting sth: The bullet deflected from the wall $\circ$ One of the defenders accidentally deflected the ball into the net $\circ$ The chairman tried to deflect the shareholders' criticism.

5. elide $v$ (linguistics) to leave out the sound of part of a word when pronouncing it: The ' $t$ ' in 'often' may be elided.

6. grandeur $n[\mathrm{U}]$ the quality of being great, magnificent and impressive in appearance or status: the beauty and grandeur of the Swiss Alps o She clearly suffers from delusions of grandeur (ie thinks she is more important than she really is).

7. lingua franca $n$ ( $p l$ lingua francas) (usu sing) a language used for communicating between people of an area in which several languages are spoken: English is becoming the lingua franca of the world.

8. ominous adj suggesting that sth bad is going to happen; threatening: an ominous silence $\circ$ Those black clouds are/look a bit ominous.

9. repulsive adj causing a feeling of strong dislike or disgust: a repulsive sight/smell / person $\circ$ Picking your nose is a repulsive habit.

10. restive adj unable to be still or quiet; difficult to control, esp because one is not satisfied with sth: Another hour passed and the crowd grew/became increasingly restive. 
Appendix II: List of test entries (definition only)

1. aftermath $n$ (usu sing) the circumstances that follow and are a consequence of an event, esp of an unpleasant one.

2. aisle $n$ a passage between rows of seats in a church, theatre, railway carriage, etc or between rows of shelves in a shop.

3. bona fide $a d j$ [esp attrib], adv genuine(ly); without deception; legal(ly).

4. deflect $v$ change or make sth change direction, esp after hitting sth.

5. elide $v$ (linguistics) to leave out the sound of part of a word when pronouncing it.

6. grandeur $n[\mathrm{U}]$ the quality of being great, magnificent and impressive in appearance or status.

7. lingua franca $n$ ( $p l$ lingua francas) (usu sing) a language used for communicating between people of an area in which several languages are spoken.

8. ominous adj suggesting that sth bad is going to happen; threatening.

9. repulsive adj causing a feeling of strong dislike or disgust.

10. restive adj unable to be still or quiet; difficult to control, esp because one is not satisfied with sth. 